\title{
ITPKAI Promotes Growth, Migration and Invasion of Renal Cell Carcinoma via Activation of mTOR Signaling Pathway [Corrigendum]
}

Zhu X, Xu A, Zhang Y, et al. Onco Targets Ther. The authors wish to apologise for this error. 2020;13:10515-10523.

The authors have advised Figure $2 \mathrm{E}$ on page 10520 is incorrect. The correct Figure 2 is as follows. 
A
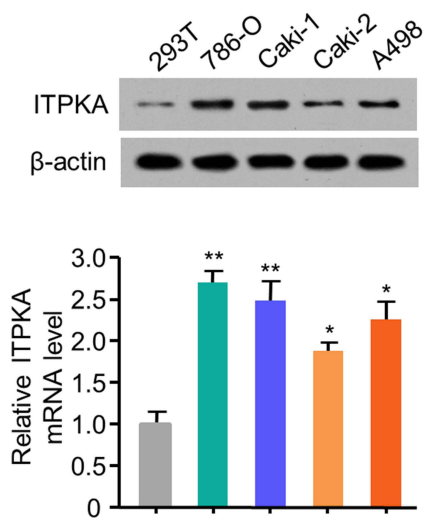

B
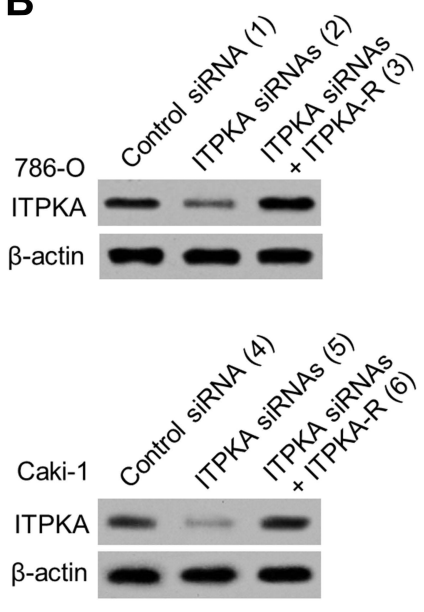

C
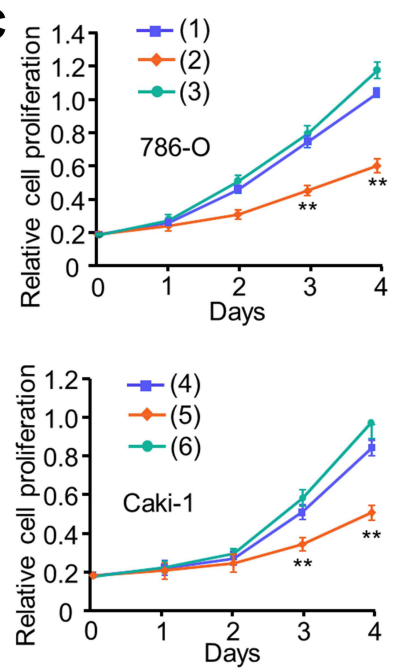

(1) (2) (3)

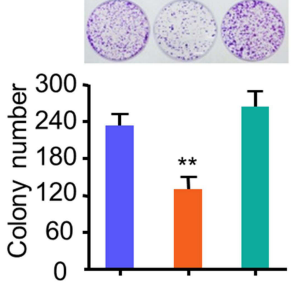

(4) (5) (6)

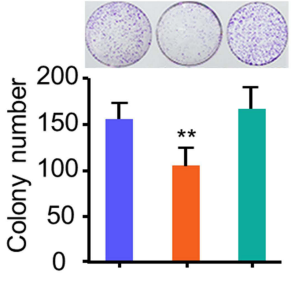

D

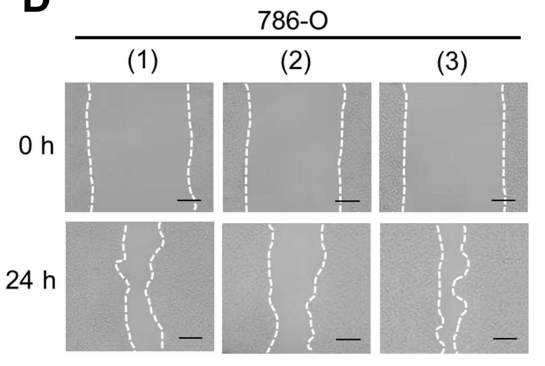

E

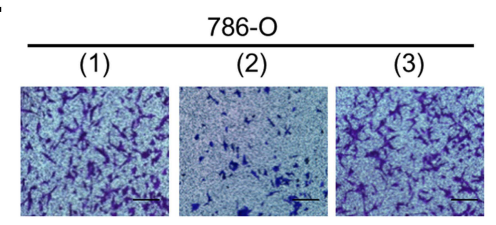

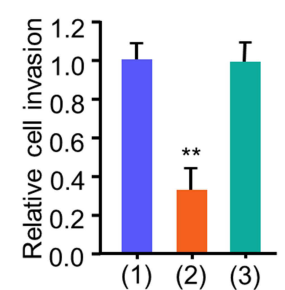

(1) (2) (3)
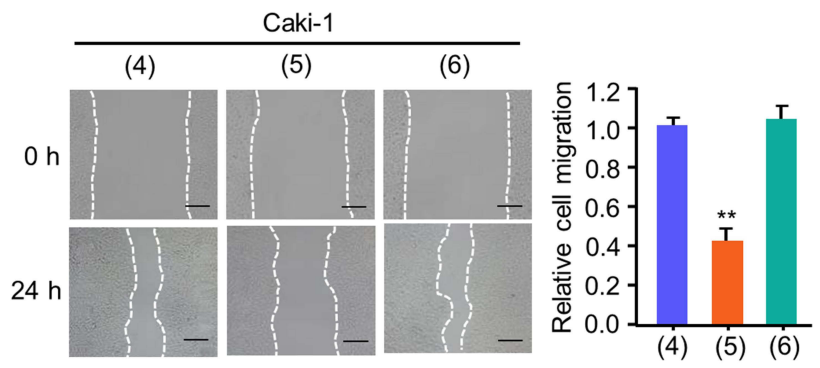

F

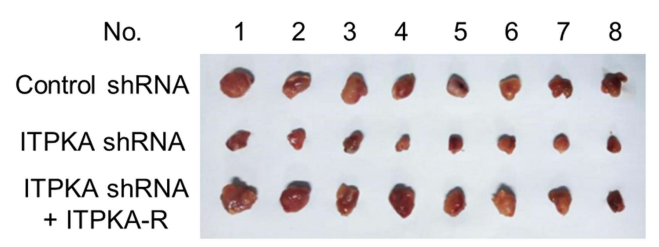

No. V (1) (2) (3)

ITPKA $=$

$\beta$-actin $=$
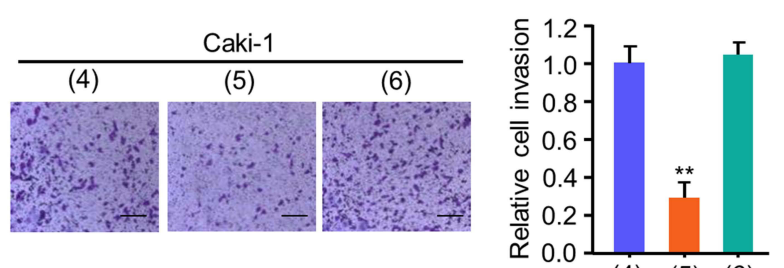

(4) (5) (6)

Figure 2 ITPKA promotes RCC proliferation, migration and invasion both in vitro and in vivo. (A) Total proteins extracted from the indicated RCC cell lines were analyzed by Western-blot with anti-ITPKA. $\beta$-actin was used as a loading control. (B) 786-O and Caki-I cells were transfected with Control siRNA or ITPKA siRNAs or ITPKA siRNAs plus ITPKA. The immunoblot shows ITPKA expression. (C) Cell proliferation and colony formation, wound healing (D) and transwell (E) assays of 786-O and Caki-I cells transfected as in (B). (I), (2), (3) represent 786-O cells transfected with Control siRNA, ITPKA siRNAs, ITPKA siRNAs plus ITPKA, respectively. (4), (5), (6) represent Caki-I cells transfected with Control siRNA, ITPKA siRNAs, ITPKA siRNAs plus ITPKA, respectively (B-D). Illustrative images show colonies in plates, cell migration and invasion. Histograms show colony number, comparative cell migration and invasion. All values displayed are mean \pm SD and have been duplicated 3 times with similar results $(\mathbf{A}-\mathbf{D})$. ${ }^{*} p<0.05$ and ${ }^{* *} p<0.01$ versus corresponding Control siRNA. (F) 786-O cells stably infected with lentivirus carrying the indicated constructs were injected into nude mice as indicated. After 28 days, mice were sacrificed to harvest tumors. At the indicated times, the tumors were measured (mean $\pm S D, n=8$ ), and the growth curve was plotted. **p $<0.01$ vs. Control shRNA group. 


\section{Publish your work in this journal}

OncoTargets and Therapy is an international, peer-reviewed, open access journal focusing on the pathological basis of all cancers, potential targets for therapy and treatment protocols employed to improve the management of cancer patients. The journal also focuses on the impact of management programs and new therapeutic

agents and protocols on patient perspectives such as quality of life, adherence and satisfaction. The manuscript management system is completely online and includes a very quick and fair peer-review system, which is all easy to use. Visit http://www.dovepress.com/ testimonials.php to read real quotes from published authors. 